\title{
Bromazepam changes performance during target shooting but does not affect the interhemispheric coupling in the theta rhythm of the electroencephalography
}

\author{
Bromazepam altera o desempenho durante o tiro ao alvo, mas não afeta o acoplamento \\ interhemisférico no ritmo teta da eletroencefalografia \\ El bromazepam altera el rendimiento durante el tiro al blanco pero no afecta al acoplamiento \\ interhemisférico en la electroencefalografía del ritmo theta
}

Received: 07/12/2021 | Reviewed: 07/17/2021 | Accept: 07/19/2021 | Published: 07/27/2021

Thayaná Ribeiro Silva Fernandes ORCID: https://orcid.org/0000-0002-6590-4620 Universidade Federal do Delta do Parnaíba, Brazil E-mail: thayana.fernandes@hotmail.com

Kaline de Melo Rocha

ORCID: https://orcid.org/0000-0001-9194-950X

Universidade Federal do Delta do Parnaíba, Brazil E-mail: kalinemrocha@gmail.com

Daya Gupta

ORCID: https://orcid.org/0000-0003-1084-9932 Camden County College, EUA E-mail: dayagup@gmail.com

Victor Marinho

ORCID: https://orcid.org/0000-0003-4800-7298

Universidade Federal do Delta do Parnaíba, Brazil E-mail: victormarinhophb@hotmail.com

Iris Moura

ORCID: https://orcid.org/0000-0003-1585-1281

Universidade Federal do Delta do Parnaíba, Brazil E-mail: iris_j_567@hotmail.com

Jacks Renan Neves Fernandes

ORCID: https://orcid.org/0000-0001-7868-0673

Universidade Federal do Delta do Parnaíba, Brazil E-mail: jacks.renan@ifpi.edu.br

Francisco Elezier Xavier Magalhães

ORCID: https://orcid.org/0000-0002-8542-4245

Universidade Federal do Delta do Parnaíba, Brazil

E-mail: fisiofranciscoxavier@gmail.com

Valécia Natália Carvalho da Silva

ORCID: https://orcid.org/0000-0001-5739-0722

Universidade Federal do Delta do Parnaíba, Brazil

E-mail: valeciacs@gmail.com

Even Herlany Pereira Alves

ORCID: https://orcid.org/0000-0001-7566-1282

Universidade Federal do Delta do Parnaíba, Brazil

E-mail: even.herlany@gmail.com

Pedro Ribeiro

ORCID: https://orcid.org/0000-0001-8270-3663

Universidade Federal do Rio de Janeiro, Brazil E-mail: ribeiropss@yahoo.com.br

Bruna Velasques

ORCID: https://orcid.org/0000-0001-9363-8932

Universidade Federal do Rio de Janeiro, Brazil

E-mail: bruna_velasques@yahoo.com.br

Victor Hugo do Vale Bastos

ORCID: https://orcid.org/0000-0001-7425-4730

Universidade Federal do Delta do Parnaíba, Brazil

E-mail: victorhugobastos@ufpi.edu.br

Silmar Silva Teixeira

ORCID: https://orcid.org/0000-0002-9240-1228

Universidade Federal do Delta do Parnaíba, Brazil

E-mail: silmateixeira@ufpi.edu.br 


\begin{abstract}
Bromazepam emulates the inhibitory effect of the neurotransmitter gamma-aminobutyric acid (GABA) and can lead to impaired visuomotor performance. However, few studies have evaluated its effects on cortical coupling in target shooting activities. The present study aimed to analyze the acute effects of bromazepam administration in a target shooting task and the EEG theta rhythm coherence between frontal, temporal, and motor cortical areas in four shooting preparation periods. Thus, a double blind, crossover study was conducted with 30 subjects under two conditions: bromazepam $(6 \mathrm{mg})$ and placebo, with electroencephalographic analysis to simultaneously study the theta rhythm coherence in frontal, temporal, and motor cortex in a target shooting task; and the possible interferences of bromazepam administration. Subjects in the bromazepam group showed lower performance on the task compared to placebo ( $\mathrm{p}=0.001)$. In addition, our analysis showed decreased coherence between regions in the same hemisphere, increased theta rhythm coherence in interhemispheric regions in frontal, temporal and motor cortex at different intervals in the preparation preceding the shooting $(\mathrm{p}=0.001)$. The use of bromazepam may influence task execution, possibly due to neurochemical modulation, during decision making, developing shooting preparation strategies, as well as interfering with the flow of information at the level of attention during task execution.
\end{abstract}

Keywords: Electroencephalography; Coherence; Theta Rhythm; Bromazepam; Target shooting.

\title{
Resumo
}

O bromazepam imita o efeito inibidor do neurotransmissor ácido gama-aminobutírico (GABA) e podem levar ao prejuízo do desempenho visuomotor. No entanto, poucos estudos avaliaram seus efeitos no acoplamento cortical em atividades de tiro ao alvo. O presente estudo objetivou analisar os efeitos agudo da administração de bromazepam numa tarefa de tiro ao alvo e a coerência do ritmo teta do EEG entre as áreas da cortical frontal, temporal, e motora em quatro períodos preparatórios de tiro. Desse modo, foi realizado um estudo crossover e duplo cego, com 30 sujeitos sob duas condições: bromazepam $(6 \mathrm{mg})$ e placebo, com análise eletroencefalográfica para estudar simultaneamente a coerência do ritmo teta no córtex frontal, temporal e motor, numa tarefa de tiro ao alvo; e as possíveis interferências da administração do bromazepam. Os sujeitos do grupo bromazepam apresentaram um desempenho inferior na tarefa em comparação com o placebo $(\mathrm{p}=0,001)$. Além disso, a nossa análise mostrou uma diminuição da coerência entre regiões no mesmo hemisfério, um aumento da coerência do ritmo teta nas regiões interhemisféricas no córtex frontal, temporal e motor em diferentes intervalos na preparação que antecedeu o tiroteio $(\mathrm{p}=0,001)$. O uso de bromazepam pode influenciar a execução da tarefa, possivelmente devido à modulação neuroquímica, durante a tomada de decisões, desenvolvendo estratégias de preparação do tiro, além de interferir com o fluxo de informação ao nível da atenção durante a execução da tarefa.

Palavras-chave: Electroencefalografia; Coerência; Ritmo Theta; Bromazepam; Tiro ao alvo.

\section{Resumen}

El bromazepam imita el efecto inhibidor del neurotransmisor ácido gamma-aminobutírico (GABA) y puede provocar un deterioro del rendimiento visuomotor. Sin embargo, pocos estudios han evaluado sus efectos sobre el acoplamiento cortical en las actividades de tiro al blanco. El presente estudio tuvo como objetivo analizar los efectos agudos de la administración de bromazepam en una tarea de tiro al blanco y la coherencia del ritmo theta del EEG entre las áreas corticales frontales, temporales y motoras en cuatro períodos de preparación de tiro. Así, se realizó un estudio cruzado y a doble ciego con 30 sujetos en dos condiciones: bromazepam $(6 \mathrm{mg})$ y placebo, con análisis electroencefalográfico para estudiar simultáneamente la coherencia del ritmo theta en la corteza frontal, temporal y motora en una tarea de tiro al blanco; y las posibles interferencias de la administración de bromazepam. Los sujetos del grupo de bromazepam mostraron un menor rendimiento en la tarea en comparación con el placebo ( $\mathrm{p}=0,001$ ). Además, nuestro análisis mostró una disminución de la coherencia entre regiones del mismo hemisferio y un aumento de la coherencia del ritmo theta en regiones interhemisféricas de la corteza frontal, temporal y motora a diferentes intervalos en la preparación que precede al disparo $(\mathrm{p}=0,001)$. El uso de bromazepam puede influir en la ejecución de la tarea, posiblemente debido a la modulación neuroquímica, durante la toma de decisiones, el desarrollo de estrategias para preparar el tiro, así como la interferencia en el flujo de información a nivel de la atención durante la ejecución de la tarea.

Palabras clave: Electroencefalografía; Coherencia; Ritmo Theta; Bromazepam; Tiro al blanco.

\section{Introduction}

Benzodiazepines (BDZs), especially bromazepam, belong to the most prescribed classes of medication used for anxiety due to its anxiolytic and hypnotic effects (Clark et al., 2013; Lino et al., 2017; Votaw et al., 2019). Bromazepam potentiates the effects of $\gamma$-aminobutyric acid neurotransmitter (GABA), which acts as a major inhibitory neurotransmitter in the central nervous system (CNS), affecting cognitive domains, such as visuospatial ability, processing speed, verbal learning 
(Stewart, 2005). This inhibitory action is through the GABA-receptor activation (GABA) (Sigel et al., 2018; Schependom et al., 2019), via allosteric sites, increasing neurotransmission (Golan et al., 2012).

In this sense, bromazepam affects perception due to the changes in inputs and neural outputs related to the learning process and muscle relaxation during the execution of visuomotor tasks (Montenegro et al., 2005; Cunha et al., 2006; Machado et al., 2009; Gongora et al., 2014; Aprigio et al., 2015). These effects could be due to increasing the reaction time during the execution of tasks; could induce greater attention level or reduce the mental effort in the performance of motor tasks (Cunha et al., 2008). Besides, Sampaio et al. (2008) showed positive effects of the acute use of bromazepam during the execution of visuomotor tasks, due to a significant reduction of stress and anxiety. However, there is controversy regarding the effects of bromazepam $(6 \mathrm{mg})$ in the target shooting tasks, since the task requires cognitive perception and a motor response depending on attention and fine motor control for the trigger pull (Janelle et al., 2000; Kerick et al., 2004; Deeny et al., 2009; Hatfield et al., 2013). These effects lead to the chances of interference of bromazepam in decision-making cognitive processes for shooting and cortical recruitment capacity during the pre-shooting period.

In general, the exploration, understanding, and monitoring of the action of BDZs in cortical activity have been analyzed in electroencephalography (EEG) (Saletu et al., 2002; Sampaio et al., 2008; Salles et al., 2006). The literature search to trace an association profile of drugs with neurophysiological functions and behavioral performance, and thus, the sensitivity and differential performance to stimuli has been associated with cortical activation patterns through energy measures within the range of theta frequency (Machado et al., 2009; Gongora et al., 2014). Also, the theta rhythm facilitates synaptic plasticity, has an influence on the reaction time, and is related to the increased attention (Buzsaki et al., 2004; Linkenkaer-Hansen et al., 2004; Womelsdorf et al., 2006). Neurophysiological analysis by EEG coherence provides evidence of coupling between cortical areas during the execution of the task (Babiloni et al., 2005; Kay et al., 2006; Jorge et al., 2007). Although the action of BDZs has been investigated with EEG analyses (Salles et al., 2006), bromazepam action is still poorly understood in the target shooting task as well as coupling strength between cortical areas at different preparation times in shooting tasks. Our goal in this study is to analyze the effects of bromazepam in a target shooting task and consistency of the EEG theta rhythm (in four time-intervals in preparation for shooting) in the frontal, temporal, and motor.

\section{Methodology}

\subsection{Subject}

The sample consisted of 60 male subjects, right-handed and healthy, aged between 20 and 30 years. There were two conditions: control (placebo) and experimental (bromazepam-6mg), and subjects were prohibited from using any substance that inhibits or stimulates brain activity (for example, tobacco, coffee, alcohol, caffeine-containing foods, or medications) $14 \mathrm{~h}$ before or during the study period (Fortunato et al., 2015; Ribeiro et al., 2018). All subjects underwent a medical evaluation to exclude those with neurological or movement disorders that impair task performance, and any contraindications to intake of bromazepam.

Upon completion of the screening, we removed 22 subjects who did not meet the criteria required for participation in the study. The remaining 38 participated in experiments in two experimental conditions: placebo and bromazepam. Later a total of 8 subjects discontinued the study; 6 did not remain for the entire duration of the study and two dropped for refusing to inge st of the capsule. Finally, the remaining 30 with a mean age \pm SD $=22 \pm 3$ years completed the entire study. The study was approved by the Ethics Committee of the Federal University of Piauí (Number 1610197) based on the Research Ethics Criteria for Human subjects as per the Declaration of Helsinki. All participants signed a consent form (Pereira et al., 2018). 


\subsection{Experimental Procedure}

Randomization: Sixty subjects were randomized at a rate of 1:1 for a double-blind experiment for two conditions in the following sequence: 15 subjects starting in the experimental condition (bromazepam-6mg use) and finishing in the control condition (placebo) and 15 subjects starting in the control condition and finishing in the experimental condition. Subjects received a 7-day washout between both conditions (Figure 1). Participants during the experiment were in a sound-proof and electrically insulated room. The resting-state EEG (i.e., 3-min in the shooting position with arm extended toward the target without the pistol to match the shooting posture employed during the conditions of interest while avoiding fatigue) was collected prior to the session commencement. There was a 2-min rest period between conditions. Later EEG data were collected during shooting tasks (EEG-task), with 1 1 1/2 hour after the placebo or bromazepam capsule ingestion (Jadad et al., 1996; Coutinho et al., 2005; Luft et al., 2006; Santos et al., 2011) (Figure 1).

Figure 1. Randomized, double-blind study design in two conditions: placebo and bromazepam, in target shooting activity with electroencephalographic signal capture.

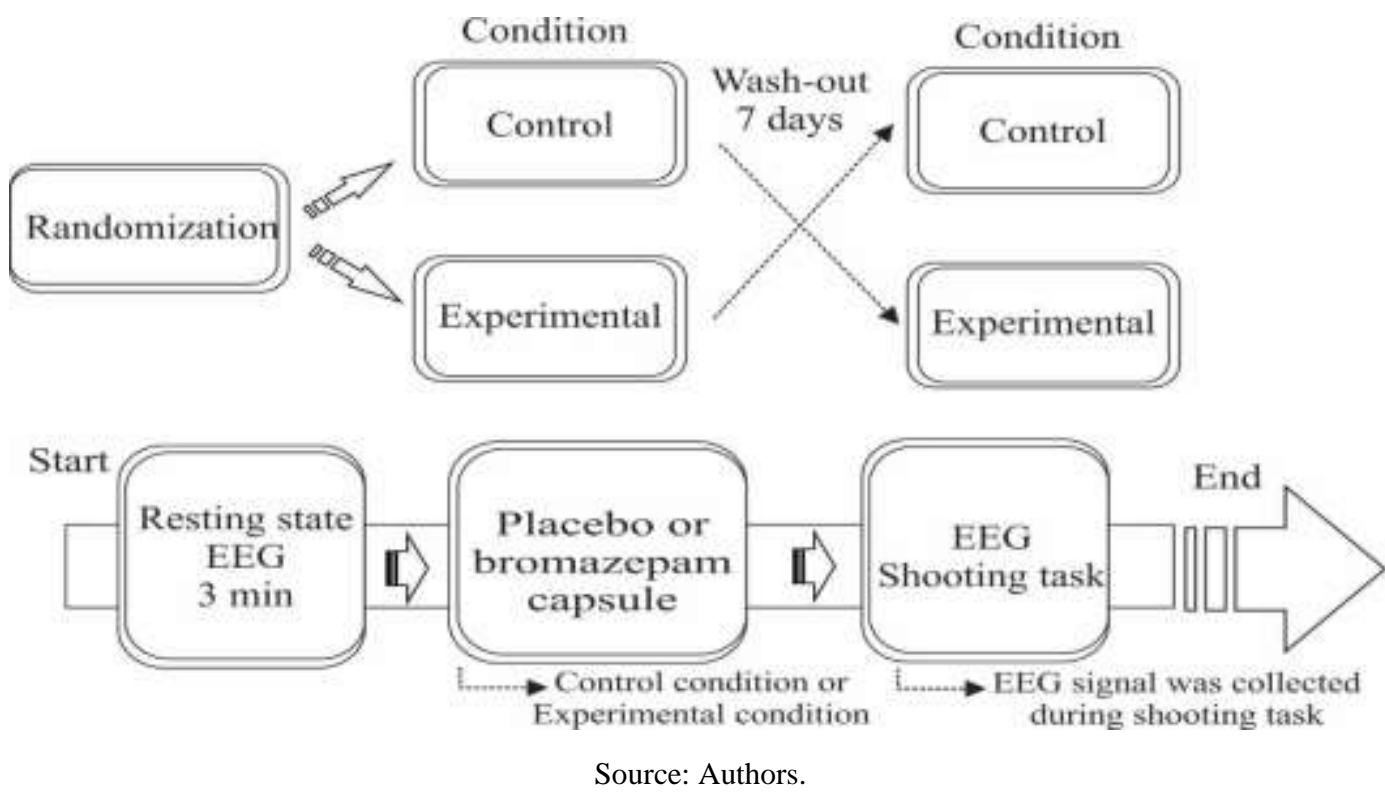

Participants employed their right (dominant) hand to complete a pistol shooting task with air pistol (Sig Sauer P226) adapted with an electromagnetic transducer to record when the movement is initiated to align with EEG signals from all trials, through an RCA connector, which we term 'Trig In.'. This device analyzes the cortical activity in the shooting preparatory period to delimit time intervals that precede the shooting. With protective goggles, subjects shooting the targets were positioned at a five-meter distance, with the targets exchange performed after each block. Participants assumed a standard shooting posture; feet positioned approximately shoulder-width apart and nearly perpendicular to the shooting lane to minimize sway. Participants extended the shooting arm, aiming their target with their right eye, while the left eye was occluded. Each condition of shooting consisted of 30 shots, which were distributed in six blocks (five shots per block) to minimize fatigue and to ensure stable estimates of the successive intervals of the attention state, leading to the trigger-pull. A two-minute interval between each block was provided for the recovery of the active limb. Such an approach reasonably allowed for the detection of dynamic change in attention during this critical period if present. The scoring was consistent with shooting scoring metrics. A paper target $(17 \times 17 \mathrm{~cm})$ was attached to a support with a collection network (Swiss Arms) with six scoring scales. Also, the target was always placed in the same position, in front of the subjects during the shooting task. The points from five to seven 
were in the scales with white coloration at the extremities, and from eight to ten in the central black circle. At the task end, the point's number was counted.

\subsection{Performance in Target Shooting Task}

The variable was obtained through subjects' performance in target shooting task. Each subject performed 30 shots, which were distributed in six blocks (five shots per block), being able to score to a maximum of 300 points. There was a good strength of agreement, with [ $\kappa=0.82 ; \mathrm{p}=0.002]$. Thus, the results support consistency in shooting task.

\subsection{EEG Recording}

The 20-channel continuous EEG was recorded by Brainet BNT36 amplifiers (EMSA-Medical Instruments, Brazil). The silver/silver chloride electrodes were positioned by an electrode lid, equidistant through a nylon cap prefixed with the international 10-20 system, including binaural reference electrodes (SPES Medical Brazil). The EEG electrode impedance was kept below $5 \mathrm{~K} \Omega$. The acquired data had an amplitude of less than $100 \mu \mathrm{V}$. The EEG signal was amplified with a gain of $22.000 \mathrm{~Hz}$, analogously filtered between $0.01 \mathrm{~Hz}$ (high-pass) and $60 \mathrm{~Hz}$ (low-pass) with $240 \mathrm{~Hz}$ using the Data Acquisition software (Delphi 5.0) developed in the Neuro-innovation Technology \& Brain Mapping Laboratory. EEG data in this study were analyzed by the Neurometrics Program (NxLink, Ltd., USA) and theta band coherence was extracted. EEGLab program was used to select the epochs of interest and remove artifacts.

\subsection{Data processing}

EEG data analysis was performed in the EEGLAB/MATLAB program. The preparatory period before the shooting, which was analyzed as pre-task epochs, comprised, $8 \mathrm{~s}$ which was divided into time intervals of $8 \mathrm{~s}$ to $6 \mathrm{~s}(\mathrm{t} 1)$, $6 \mathrm{~s}$ to $4 \mathrm{~s}$ (t2), $4 \mathrm{~s}$ to $2 \mathrm{~s}(\mathrm{t} 3)$, and $2 \mathrm{~s}$ to 0 (t4). Time zero corresponds to the trigger moment. Contaminated extracts by muscular artifacts and ocular movements were excluded from the analysis using a rejection criterion of $\pm 100 \mu \mathrm{V}$ in any channel, and independent component analysis (ICA) was applied to identify and remove all remaining artifacts produced by the task (Brauns et al., 2014; De Carvalho et al., 2015). Electrode data that showed contact loss with scalp or high impedance ( $>5 \mathrm{~K} \Omega$ ) were excluded. A classical estimator was applied to the spectral power density, estimated from the Fourier Transform, which was performed by MATLAB (Matwords, Inc.). After the removal of the artifacts, the remaining components were inserted back to recompose the electrode signal, where only the remaining epochs were part of the subsequent signal processing and statistical analysis.

We analyzed the theta band coherence: total theta $(4-7 \mathrm{~Hz})$ in electrode positions on the scalp: C3-C4, F3-C3, F3-F4, F3-T3, F4-C4, F4-T4, and T3-T4. The electrodes were selected to represent the dorsolateral prefrontal cortex (DLPFC) left and right, the primary motor cortex (PMC) left and right, and posterior temporal cortex (PTC) left and right respectively, which play key roles in decision-making, working memory, executive attention, motor preparation and inhibition (Homan et al., 1987; Hatfield et al., 2013).

\subsection{Statistical analysis}

The subjects' performance was analyzed by paired t-test between placebo and bromazepam conditions. For the neurophysiological variables' analysis, a three-way repeated-measures ANOVA was performed with following three factors: conditions (resting-state vs. placebo vs. bromazepam); electrodes (C3-C4 vs. F3-C3 vs. F3-F4 vs. F3-T3 vs. F4-C4 vs. F4-T4 vs. T3-T4); and shooting preparatory periods $\left(\mathrm{t}_{1} v s . \mathrm{t}_{2} v s . \mathrm{t}_{3} v s . \mathrm{t}_{4}\right)$. Three factors' interactions were investigated by two-way repeated-measures ANOVA, while two factors interactions were investigated by the Student t-test, and one-way ANOVA was further analyzed by the post hoc test if necessary. Besides, binary logistic regression was used to investigate the association 
between the conditions (dependent variable) and EEG theta dynamics in each pairing of electrodes corresponding to the cortical areas during each preparatory period (independent variables).

Partial $\eta^{2} p$ is used as a measure of effect size for the repeated measures analysis while Cohen's $d$ is used for the Student $\mathrm{t}$-test. Statistical power and the 95\% confidence interval (95\% CI) were calculated for the dependent variables. Statistical power was interpreted as low power from 0.1 to 0.3 ; high power from 0.8 to 0.9 . Effect magnitude was interpreted using the recommendations suggested by Cohen (1988): insignificant <0.19; small from 0.20 to 0.49 ; mean from 0.50 to 0.79 ; large from 0.80 to 1.29 . The probability of $5 \%$ for type I error was adopted in all analyzes ( $\leq 0.05$ ), with alpha-Bonferroni correction for the interaction analysis, adjusting the value for $\mathrm{p} \leq 0.025$. Analyzes were conducted in SPSS for Windows version 20.0 (SPSS Inc., Chicago, Il, USA).

\section{Results}

\subsection{Performance in shooting task}

The findings of the paired t-test and Cohen's indicated that the acute bromazepam use produced an association average effect on subjects' performance on shooting tasks $[t(26)=2.53 ; \mathrm{p}=0.018 ; \mathrm{d}=0.5]$, promoting a lower hit score during the shooting task (Figure 2).

Figure 2. Performance of the subjects in the execution of the target shooting task. Significant differences $(\mathrm{p}<0.05)$ between conditions are represented by the asterisk $(*)$.

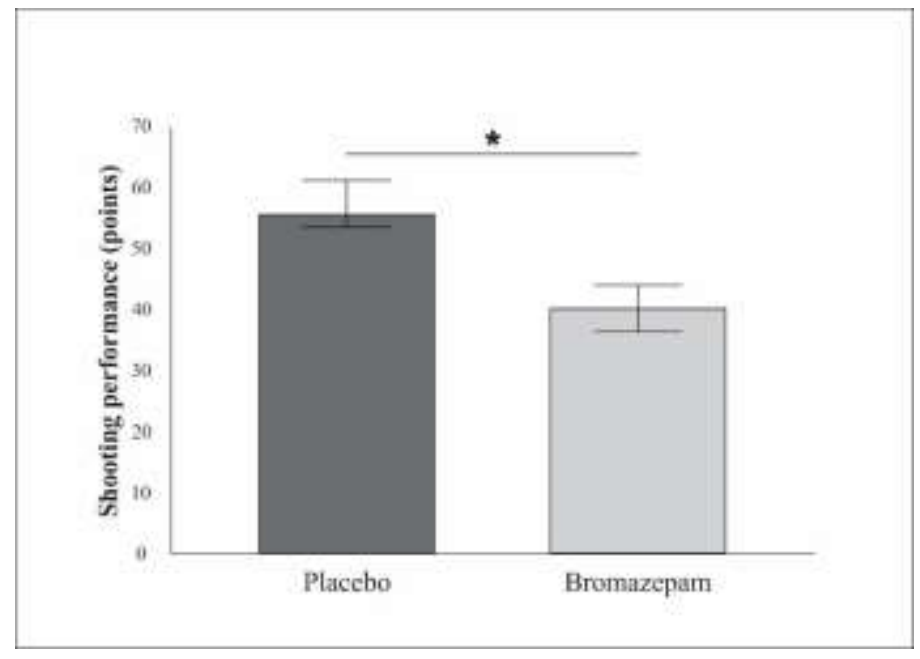

Source: Authors.

\subsection{Neurophysiological results}

The use of bromazepam resulted in the reduction of coupling between the cortical areas through the pairing of the electrodes $\mathrm{F} 3-\mathrm{C} 3$ and $\mathrm{T} 3-\mathrm{T} 4$, in all preparatory periods, which demonstrates joint actions of these regions in the planning necessary for the execution of the task (Table 1; Figure 3). Moreover, in the F3-C3 electrodes main effect was observed in placebo condition with $\left[\mathrm{F}(3.67,0.13)=27.53 ; \mathrm{p}=0.001 ; \mathrm{n}^{2} \mathrm{p}=0.14 ;\right.$ power $\left.=100 \%\right] \mathrm{F} 4-\mathrm{C} 4$ and with $[\mathrm{F}(2.39 ; 0.09)=26.53$; $\mathrm{p}=0.001 ; \eta^{2} \mathrm{p}=0.14$; power $\left.=100 \%\right]$, suggesting that the administered dosage of the drug wasn't sufficient to interfere in the coupling between areas (Figure 4). In C3-C4 coactivation was no increase in pairs between the cortical areas having main effect for bromazepam condition with $\left[\mathrm{F}(1,16 ; 0,01)=153.21 ; \mathrm{p}=0.001 ; \eta^{2} \mathrm{p}=0.69\right.$; power $\left.=100 \%\right]$ for F3-F4: $[\mathrm{F}(8.63$; $0.03)=325.28 ; \mathrm{p}=0.001 ; \eta^{2} \mathrm{p}=0.72 ;$ power $\left.=100 \%\right]$ and $\mathrm{F} 4-\mathrm{T} 4$ with $\left[\mathrm{F}(2.61 ; 0.01)=279.24 ; \mathrm{p}=0.001 ; \eta^{2} \mathrm{p}=0.07 ;\right.$ power $=$ 
$100 \%$ ], which indicates a better neuronal response to the drug (Figure 5). Moreover, also showed significant main effect for pre-shooting preparation time F3-F4: $\left[\mathrm{F}(0.07 ; 0.01)=6.68 ; \mathrm{p}=0.001 ; \eta^{2} \mathrm{p}=0.05 ;\right.$ Power $\left.=97 \%\right]$ and F4-T4: $[\mathrm{F}(0.04 ; 0.01)=$ $5.55 ; \mathrm{p}=0.002 ; \eta^{2} \mathrm{p}=0.06 ;$ Power $\left.=92 \%\right]$, demonstrating increased latency to start task execution (Figure 6).

Table 1. Interaction analysis of the condition factors and preparatory periods of the shot. Statistical differences ( $\mathrm{p} \leq 0.05)$ are represented by the asterisk $(*)$.

\begin{tabular}{cccccc}
\hline Variables & $\hat{\boldsymbol{\varepsilon}}$ & $\mathbf{F}$ & $\mathbf{P}$ & $\mathbf{\eta}^{\mathbf{2}} \mathbf{p}$ & Power (\%) \\
\hline F3-T3 & $0.04 ; 0.01$ & 5.61 & $0.001 *$ & 0.08 & $98 \%$ \\
T3-T4 & $0.04 ; 0.01$ & 4.21 & $0.001 *$ & 0.03 & $95 \%$ \\
\hline
\end{tabular}

Source: Authors.

Figure 3. The behavior of the theta rhythm coherence in the pairs of electrodes F3-T3 (A) and T3-T4 (B) showing the interactions between the preparatory periods for shooting in resting, placebo and bromazepam conditions. Significant statistical differences between conditions were demonstrated by means of mean and standard error and are represented by asterisks $(*)$.
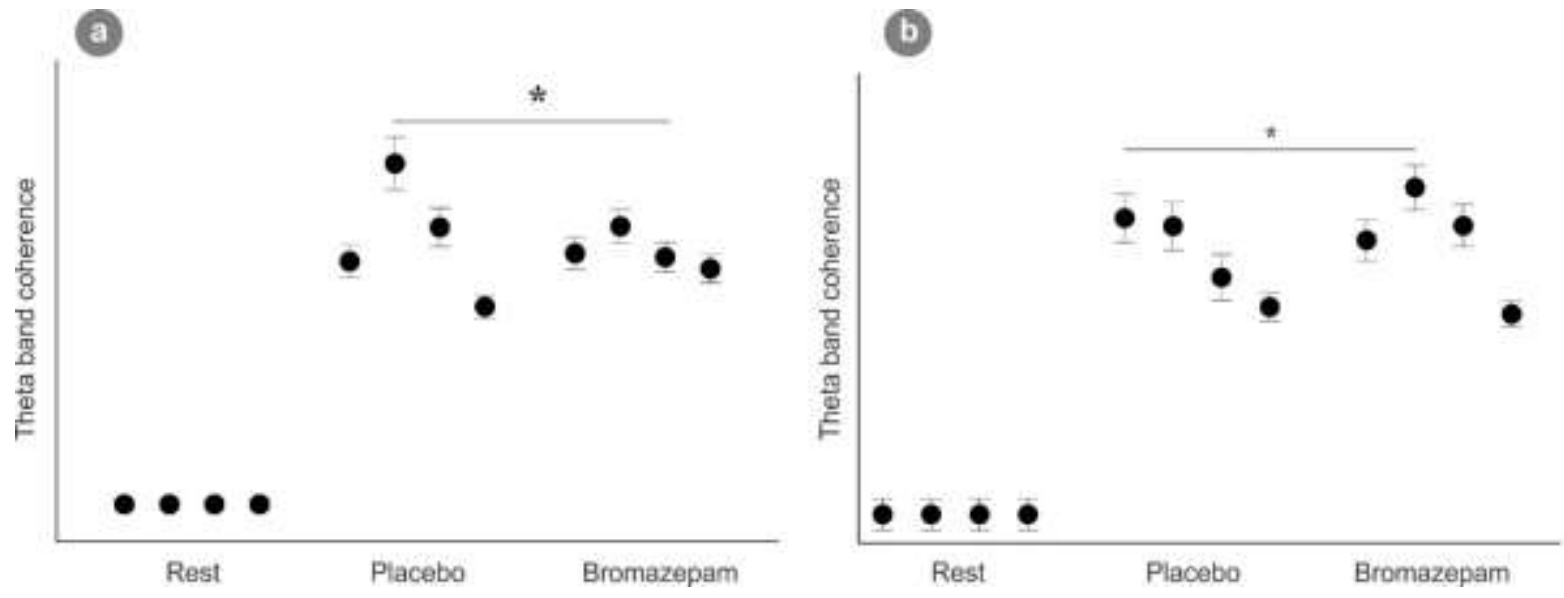

Source: Authors.

Figure 4. The behavior of the theta rhythm coherence in the electrode pairs F3-C3 (A) and F4-C4 (B) showing the main effect for placebo condition. Statistical differences between conditions were demonstrated by means of mean and standard error and are represented by asterisks $(*)$.
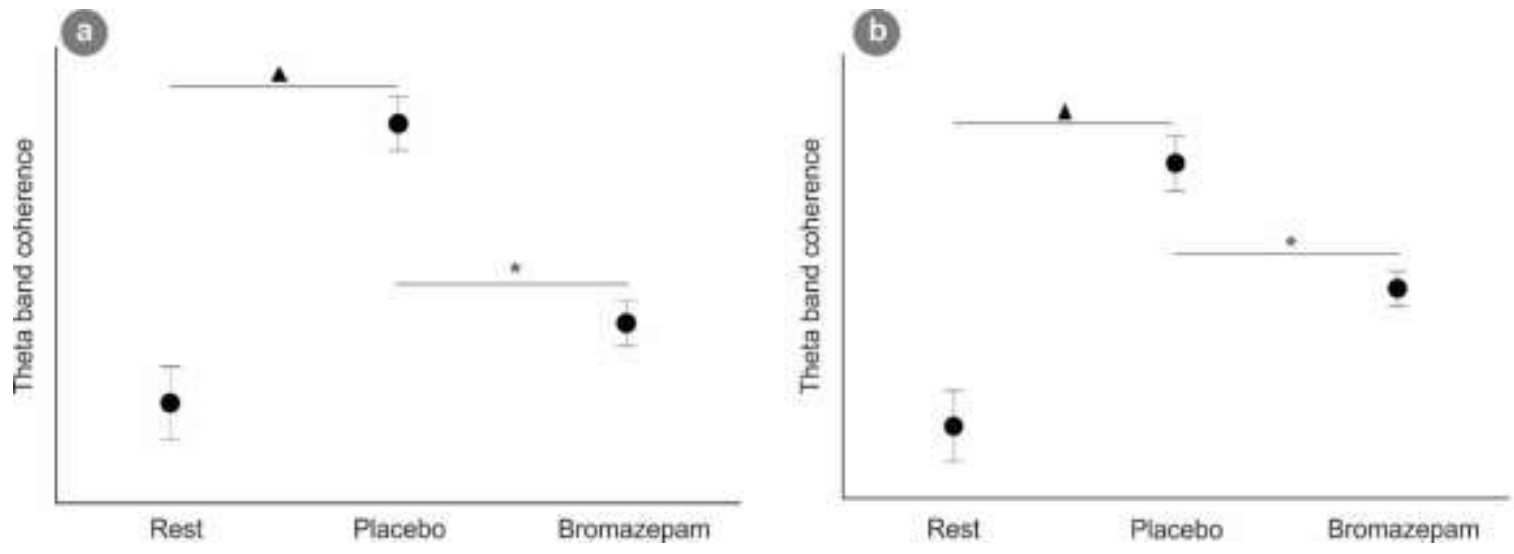

Source: Authors. 
Figure 5. The behavior of the theta rhythm coherence in electrode pairs C3-C4 (A), F3-F4 (B) and F4-T4 (C) showing the main effect for bromazepam condition. The statistical differences between the conditions were demonstrated by means of the mean and standard error and are represented by asterisks $(*)$.

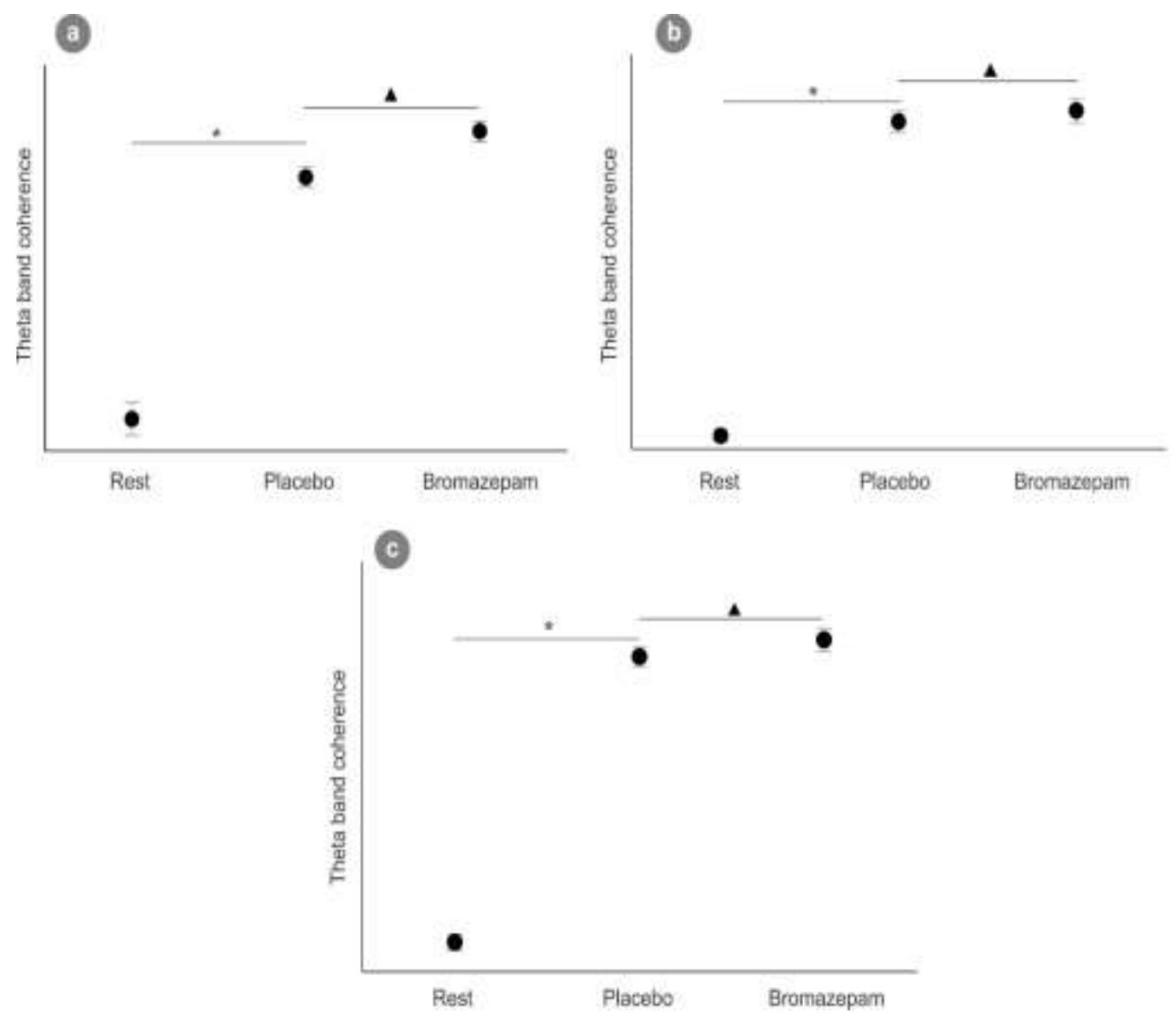

Source: Authors. 
Figure 6. The behavior of the theta rhythm coherence showing the main effect for the time in the pairs of electrodes F3-F4 (A) with increased coupling in the preparatory period t2 and F4-T4 (B) in the preparatory period t1. The strategic differences between the preparatory periods were demonstrated by means of the mean and standard error and are represented by asterisks $(*)$.
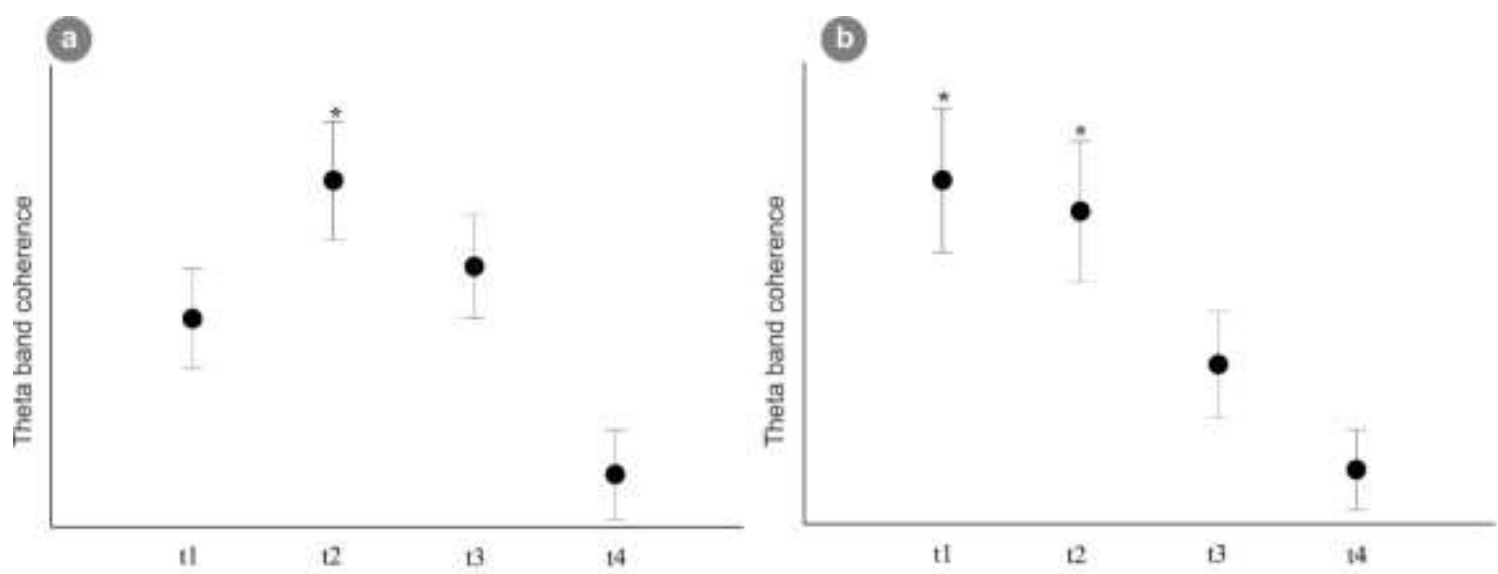

Source: Authors.

\subsection{Association of the effect of bromazepam on cortical áreas}

The regression model showed no association between the use of bromazepam and the changes in cortical activity in the dorsolateral prefrontal cortex, temporal cortex, primary motor cortex bilaterally in the preparatory periods for different shooting tasks ( $\mathrm{p}>0.05)$ (Table 2). 
Table 2. Association between bromazepam use and neurophysiological variables for each preparatory period for shooting. Abreviations: $\mathrm{B}=$ regression coefficient; $\mathrm{SE}=$ standard error; $\mathrm{df}=$ degreeof freedom; $\mathrm{C} 3=$ left motor cortex; $\mathrm{C} 4=$ right $\mathrm{motor}$ cortex; F3 = left dorsolateral prefrontal cortex; F4 = right dorsolateral prefrontal cortex; T3 = left temporal cortex; T4 = right temporal cortex. $\mathrm{t} 1=$ time $1(8$ to $6 \mathrm{~s}) ; \mathrm{t} 2=$ time 2 ( 6 to $4 \mathrm{~s}) ; \mathrm{t} 3=$ time 3 ( 4 to $2 \mathrm{~s}$ ) e $\mathrm{t} 4=$ time 4 ( $2 \mathrm{~s}$ to 0 ). Significant differences $(\mathrm{p}<0.05)$ are represented by the asterisk $(*)$.

\begin{tabular}{|c|c|c|c|c|c|c|c|c|}
\hline Variables & B & S.E & Wald & $d f$ & $\mathbf{p}$ & Odds Ratio & \multicolumn{2}{|c|}{$\begin{array}{l}\text { CI } 95 \% \text { for } \\
\text { Odds Ratio }\end{array}$} \\
\hline C3-C4_t1 & 1.18 & 1.30 & 0.81 & 1 & 0.36 & 3.25 & 0.25 & 42.04 \\
\hline C3-C4_t2 & -0.76 & 1.21 & 0.39 & 1 & 0.53 & 0.46 & 0.04 & 5.05 \\
\hline C3-C4_t3 & 0.79 & 1.29 & 0.37 & 1 & 0.53 & 2.22 & 0.17 & 28.26 \\
\hline C3-C4_t4 & -1.15 & 1.42 & 0.65 & 1 & 0.41 & 0.31 & 0.01 & 5.15 \\
\hline F3-C3_t1 & -0.43 & 0.82 & 0.28 & 1 & 0.59 & 0.64 & 0.13 & 3.23 \\
\hline F3-C3_t2 & -0.48 & 0.87 & 0.30 & 1 & 0.58 & 0.61 & 0.11 & 3.39 \\
\hline F3-C3_t3 & -0.19 & 0.86 & 0.05 & 1 & 0.81 & 0.82 & 0.15 & 4.46 \\
\hline F3-C3_t4 & -0.72 & 0.80 & 0.81 & 1 & 0.36 & 0.48 & 0.10 & 2.34 \\
\hline F3-F4_t1 & -1.43 & 1.15 & 1.54 & 1 & 0.21 & 0.23 & 0.02 & 2.28 \\
\hline $\mathrm{F} 3-\mathrm{F} 4$ - $\mathrm{t} 2$ & -1.14 & 1.06 & 1.14 & 1 & 0.28 & 0.31 & 0.04 & 2.58 \\
\hline F3-F4_t3 & -0.05 & 1.05 & 0.00 & 1 & 0.95 & 0.94 & 0.11 & 7.51 \\
\hline F3-F4_t4 & -0.32 & 1.03 & 0.09 & 1 & 0.75 & 0.72 & 0.09 & 5.52 \\
\hline F3-T3_t1 & -1.25 & 1.21 & 1.06 & 1 & 0.30 & 0.28 & 0.02 & 3.09 \\
\hline F3-T3_t2 & 2.43 & 1.26 & 3.67 & 1 & 0.05 & 11.37 & 0.94 & 136.68 \\
\hline F3-T3_t3 & -1.37 & 1.30 & 1.11 & 1 & 0.29 & 0.25 & 0.02 & 3.24 \\
\hline F3-T3_t4 & 0.37 & 1.34 & 0.07 & 1 & 0.78 & 1.44 & 0.10 & 20.31 \\
\hline F4-C4_t1 & 1.18 & 0.92 & 1.64 & 1 & 0.19 & 3.27 & 0.53 & 19.99 \\
\hline $\mathrm{F} 4-\mathrm{C} 4$ _t 2 & 0.19 & 0.90 & 0.04 & 1 & 0.83 & 1.21 & 0.20 & 7.16 \\
\hline F4-C4_t3 & -1.15 & 0.91 & 1.58 & 1 & 0.20 & 0.31 & 0.05 & 1.90 \\
\hline F4-C4_t4 & 0.30 & 0.85 & 0.12 & 1 & 0.72 & 1.36 & 0.25 & 7.31 \\
\hline F4-T4_t1 & 2.37 & 1.37 & 3.00 & 1 & 0.08 & 10.77 & 0.73 & 158.28 \\
\hline F4-T4_t2 & -1.86 & 1.28 & 2.11 & 1 & 0.14 & 0.15 & 0.01 & 1.91 \\
\hline F4-T4_t3 & 0.59 & 1.29 & 0.21 & 1 & 0.64 & 1.81 & 0.14 & 22.90 \\
\hline F4-T4_t4 & 1.33 & 1.40 & 0.90 & 1 & 0.34 & 3.80 & 0.24 & 59.70 \\
\hline T3-T4_t1 & -0.63 & 1.12 & 0.31 & 1 & 0.57 & 0.53 & 0.05 & 4.80 \\
\hline T3-T4_t2 & 1.47 & 1.07 & 1.86 & 1 & 0.17 & 4.35 & 0.52 & 35.93 \\
\hline T3-T4_t3 & 0.18 & 1.09 & 0.02 & 1 & 0.86 & 1.20 & 0.14 & 10.26 \\
\hline T3-T4_t4 & 2.06 & 1.36 & 2.29 & 1 & 0.13 & 7.86 & 0.54 & 113.24 \\
\hline
\end{tabular}

Source: Authors.

\section{Discussion}

The present study investigated the performance of the target shooting task and the spectral coherence of the theta rhythm in the dorsolateral prefrontal cortex, temporal, and motor cortex mover in four preparatory time-intervals $\left(\mathrm{t}_{1}(8 \mathrm{~s}\right.$ to $6 \mathrm{~s})$ $t_{2}(6 s$ the $4 s) t_{3}(4 s 2 s)$ and $t_{4}(2 s$ to $0 s)$ after a dose of bromazepam $(6 \mathrm{mg})$. The hypothesis that bromazepam decreases coactivation between the cortical areas as analyzed by EEG in the pre-trigger period has been generally supported by our study.

The results for the coherence between the left dorsolateral prefrontal cortex (DLPFC) and the right temporal cortex showed an increase in coherence with the bromazepam condition. The increase in coherence indicates the joint effort of both hemispheres to facilitate the planning and organization of the required sequence to the anticipation of the motor act and subsequent execution of the task (Koeneke et al., 2004; Beudel et al., 2011). The increase in coherence between the temporal lobe and DLPFC on the left hemisphere in the placebo condition may reflect a more precise sensorimotor neural network the cortico-striatal-thalamo-cortical approach tract at the time of the shooting task (Ghafouri et al., 2004; Desmurge et al., 2009). Besides that, the inhibitory effect of bromazepam attenuates the coupling between cortical areas (Deakin et al., 2004; Makaron 
et al., 2013) since it changes the sustained attention to the task performance. This is due to the deficits in neural inputs of sensorimotor transmission functionally assigned to the left temporal cortex, after the use of bromazepam led to changes in the synchronization information transmitted to the sensory receptors in cortical areas, thus hampering the processing of visual stimuli for motor tasks, resulting from the decrease in processing information necessary for the execution of the motor task (Schreckenberger et al., 2004; Ahveninen et al., 2007; Araújo et al., 2011; Muñoz-Torres et al., 2011; Ongone et al., 2019).

The decreased coherence between the left DLPFC with the left motor cortex, and between the right DLPFC with the right motor cortex demonstrated that the subjects under the condition bromazepam showed a decrease in the coupling between the cortical centers in the same hemisphere, processing the visuomotor response as compared to the placebo condition. In the learning of bimanual tasks, there is an initial increase in the coherence between hemispheres, which is followed by a late decline (Andres et al., 1999). This suggests that interhemispheric coherence does not play a direct role in the execution of tasks but may affect other aspects of motor control in a task, which becomes the dominant bromazepam condition. Portella et al. (2006) to study motor learning in a typewriting task after bromazepam (6 mg) administration, the observed reduction of coherence in scalp regions, which reflected a decrease in the tone patterns and muscular strength expended for execution the task, being understood as acquisition memory processes (Bastos et al., 2005; Summerfield et al., 2005).

The findings of the cortex motor left and right DLPFC shows increased coherence about the subjects of the placebo condition, which we argue is due to increased coherence between the cortex left motor and the right is associated with the neuromodulatory effect of bromazepam on motor task. This is likely due to decreased cognitive actions such as anxiety, which consequently increases the excitatory actions of GABA (Salles et al., 2006; Gulledge et al., 2006; Sampaio et al., 2007; Minc et al., 2009). In this sense, the preparation for task execution can be a result of significant neuronal response of visual intervals modulation, based on GABA levels, directly affecting the reactivity and attention, levels of anxiety, and muscle tone (Eagleman et al., 2009; Sadeghi et al., 2011; Mayo et al., 2013).

Among the right and left DLPFC, increased coherence was observed, which indicates that the cortical inhibition produced by bromazepam can increase the efficiency of crosstalk between areas (Sampaio et al., 2007). Also, the findings in this study show greater functional coherence between right DLPFC and temporal lobe, which consequently can promote damage in the neuronal flow of information to the essential neurobiological domains during the execution of the task (Andres et al., 1999) increasing the strength of the links and promoting functional coupling between cortical areas (Sampaio et al., 2007).

We note that the coherence of the theta rhythm between the left DLPFC and right DLPFC was higher in the preparatory period of 6 to $4 \mathrm{~s}(\mathrm{t} 2)$, but with a reduction of 2 to $0 \mathrm{~s}(\mathrm{t} 4)$, which indicates an increase in the state of latency to start the task, reducing the performance of the shot (Makaron et al., 2013). Furthermore, when (Haufler et al., 2000) studied the comparative EEG profiles of trained and novice shooters with a visuospatial task, they noted that the six-second range shooters had greater familiarity with the shot. As well as for left DLPFC and temporal lobe, in which the coupling was higher both in the period of 8 to $6 \mathrm{~s}(\mathrm{t} 1)$ and for the period of 6 to $4 \mathrm{~s}(\mathrm{t} 2)$ and decreased between 2 and 0 (t4). This result was also found by Hatfield et al. (1984) and Kerick et al. (2001), in the preparatory period of 7.5 to $8 \mathrm{~s}$ when studying the performance of skilled shooters, in which they concluded that there was an increase in power in the alpha rhythm.

There are some limitations to the present study. This study did not include female subjects, which could demonstrate gender differences in bromazepam affects. This study did not use female subjects due to the biases in the EEG signal resulting from female hormone variations. The other limitation refers to the lack of study of attention and memory. Finally, a single dose administration based on dose/weight may have had other effects on neurophysiological analysis, which could be only detected by a dose-response curve. 


\section{Conclusion}

This study shows a decrease in target shooting performance after bromazepam administration in healthy non-skilled individuals. In addition, some results show a decrease in coherence after bromazepam ingestion, which indicates a decreased synchronism of cortical activity in some regions, which act on the level of attention and motor adjustment for task performance. However, in addition to these results, we also observed some findings of increased interhemispheric coactivation, suggesting that bromazepam use acts to cause greater synchronization of cortical areas. This shows that specific interhemispheric areas work together, consequently enhancing neural synchronism.

Therefore, one can reach the conclusion that the use of bromazepam can influence task execution, since it acts in modulating the neurochemical pathway during decision making in preparation for the shooting task. In addition, it is capable of interfering with the flow of information in the modulation of attention for the execution of the task. Also, to complement the research, future studies may use longer time windows to identify other events in cortical activities, as well as long-term followup with the use of bromazepam, to understand the effects associated with the administration of the anxiolytic to the shooting task.

\section{References}

Ahveninen, J, et al. (2017). MRI - constrained spectral imaging of benzodiazepine modulation of spontaneous neuromagnetic activity in human cortex. Neuroimage, 35: 577-582.

Andres, F. G., et al. (1999). Functional coupling of human cortical sensorimotor areas during bimanual skill acquisition. Brain, 122: 855-870.

Aprigio, D., et al. (2015). Alpha power oscillation in the frontal cortex under Bromazepam and Modafinil effects. Arq Neuropsiquiatr, 73(11):918-23.

Araújo, F., et al. (2011). The effects of bromazepam over the temporoparietal áreas during the performance of a visuomotor task: a qEEGstudy. Neurosci. Lett, 496(2):116-120.

Babiloni, C., et al. (2005). Anticipation of somatosensory and motor events increases centro-parietal functional coupling: an EEG coherence study. Clin Neurophysiol, 117(5): 1000-8.

Bastos, V. H., et al. (2005). Electroencephalography measures in motor skill learning and effects of bromazepam. Arq. Neuro-Psiquiatr, 63(2B): 443-451.

Beudel, M., et al. (2011). Secondary sensory area SII is crucially involved in the preparation of familiar movements compared to movements never made before. Hum Brain Mapp, 32(4):564-579.

Brauns, I., et al. (2014). Changes in the theta band coherence during motor task after hand immobilization. Int Arch Med, 7: 51.

Buzsaki, G., \& Draguhn, A. (2004). Neuronal oscillations in cortical networks. Science, 304(5679): 1926-1929.

Clark, M., et al. (2013). Pharmacology illustrate. Artmed.

Coutinho, E. S. F., \& Cunha, G. M. (2005). Basic concepts of epidemiology and statistics for reading controlled clinical trials. Rev Bras Psiquiatr. 27: 146-51.

Cunha, M, et al. (2006). Neuromodulatory effect of bromazepam on motor learning: an electroencephalographic approach. Neurosci Lett, 407(2): 166-70.

Cunha, M., et al. (2008). Responsiveness of sensorimotor córtex during pharmacological intervention with bromazepam. Neurosci Lett, 448(1): 33-6.

De Carvalho, M. R., et al. (2015). Frontal córtex absolute beta power measurement in Panic Disorder with Agoraphobia patients. Journal of Affective Disorders, 176-181.

Deakin, J. B., et al. (2004). Diazepam produces disinhibitory cognitive effects in male volunteers. Psychopharmacology (Berl), $173(1-2)$ : 88-97.

Deeny, S. P., et al. (2009). Electroencephalographic coherence during visuomotor performance: a comparison of cortico-cortical communication in expert and novice. Journal of Motor Behavior, 41(2): 106-116.

Desmurge, M., \& Sirigu, A. (2009). A parietal-premotor network for movement intention and motor awareness. Trends Cogn Sci., 13(10): 411-9.

Eagleman, D. M., \& Pariyadath, V. (2009). Is subjective duration a signature of coding efficiency? Philos. Trans. R. Soc Lond B BiolSci, 364(1525): 18411851 .

Fortunato, S., et al. (2015). The effects of bromazepam over the central and frontal areas during a motor task: an EEG study. Arq Neuro Psrquiatr, 73(4): 3219 . 
Ghafouri, M., et al. (2004). Initiation of rapid reach-and-grasp balance reactions: is a pre-formed visuospatial map used in controlling the initial arm trajectory? Exp Brain Res, 155(4): 532-536.

Golan, D. E. (2012). Princípios de farmacologia: a base fisiopatológica da farmacoterapia. Guanabara Koogan.

Gongora, M., et al. (2014). Absolute Theta Power in the Frontal Cortex During a Visuomotor Task: The Effect of Bromazepam on Attention. Clin EEG Neurosci, 46(4): 292-8.

Gulledge, A. T., \& Stuart, G. J. (2003). Excitatory actions of GABA in the cortex. Neuron, 37: 299-309.

Hatfield, B. D., et al. (2013). The influence of social evaluation on cerebral cortical activity and motor performance: a study of "real-life" competition. Int. J. Psychophysiol, 90(2): 240-249.

Hatfield, B. D., et al. (1984). Cognitive processes during self-paced motor performance: an electroencephalographic profile of skilled marksmen. $J$ Sport Psychol, 6:42-59.

Haufler, A. J., et al. (2000). Neuro-cognitive activity during a self-paced visuospatial task: Comparative EEG profiles in marksmen and novice shooters. Biol Psychol, 53:131-160.

Homan, R. W., et al. (1987). Cerebral location of international 10-20 system electrode placement. Electroencephalogr Clin Neurophysiol. Apr, 66(4): 376-82.

Janelle, C. M., et al. (2000). Expertise differences in cortical activation and gaze behavior during rifle shooting. Journal of Sport \& ExercisePsychology, 22(2): 167-182.

Jadad, A. R., et al. (1996). Assessing the quality of reports of randomized clinical trials: is blinding necessary? Control Clin Trials. 17: 1-12.

Jorge, M. S., et al. (2007). Study of interhemispheric coherence on healthy adults. ArqNeuropsiquiatr, 65(2B): 377-80.

Kay, L. M. (2006). Theta oscillations and sensorimotor performance. Proceedings of the National Academy of the EUA, 102(10): 3863-3868.

Kerick, S. E., et al. (2004). Cerebral cortical adaptations associated with visuomotor practice. Med Sci Sports Exerc, 36(1): 118-29.

Kerick, S. E., et al. (2001). The role of the left temporal region under the cognitive-motor demands of shooting in skilled marksmen. Biol Psychol, 58(3): 263277.

Koeneke S, et al. (2004). Bimanual versus unimanual coordination: what makes the difference? NeuroImage, 22(3): 1336-1350.

Linkenkaer-Hansen, K., et al. (2004). Pre-stimulus oscillations increase psychophysical performance in humans. J Neurosci, 24: 10186-10190.

Lino, P. A., et al. (2017). Anxiolytics, Sedatives, and Hypnotics Prescribed by Dentists in Brazil in 2010. Biomed Res Int. 2841549.

Luft, C.; \& Andrade, A. (2006). A pesquisa com EEG aplicada à área de aprendizado motor. Revista Portuguesa de Ciências e Desporto. 6: 106-115.

Machado D, et al. (2009). The effects of bromazepam on the performance of a sensory-motor activity: an electroencephalographic study. RevNeurol, 49(6): 295-9.

Makaron, L., et al. (2013). Cognition-impairing effects of benzodiazepine-type drugs: role of GABAA receptor subtypes in an executive function task in rhesus monkeys. Pharmacol Biochem Behav, 104: 62-8.

Mayo, J. P., \& Sommer, M. A. (2013). Neuronal correlates of visual time perception at brief timescales. Proc Natl AcadSci USA, 110(4): 1506-11.

Minc D, et al. (2009). Gamma band oscillations under influence of bromazepam during a sensorimotor integration task: An EEG coherence study. Neuroscience Letter, 469: 145-149.

Montenegro, M., et al.. (2005). Neuromodulatory effects of caffeine and bromazepam on visual event-related potential (P300): a comparative study. Arq Neuro-Psiquiatr, 63(2B): 410-5.

Muñoz-Torres, Z., et al. (2011). Diazepam-induced changes in EEG oscillations during performance of a sustained attention task. J Clin Neurophysiol, 28(4): $394-9$.

Nguema Ongone, T., et al. (2019). Synthesis of Surfactants Derived from 2-Mercaptobenzimidazole and Study of Their Acute Toxicity and Analgesic and Psychotropic Activities. Biochemistry research international, 9615728.

Pereira A. S., et al. (2018). Metodologia da pesquisa cientifica. [UFSM. https://repositorio.ufsm.br/bitstream/handle/1/15824/Lic_Computacao_MetodologiaPesquisa-Cientifica.pdf?sequence $=1$.

Portella, C. E., et al. (2006). Procedural learning and anxiolytic effects: electroencephalographic, motor and attentional measures. Arq Neuro-Psiquiatr, 64(2B); 478-484.

Ribeiro, J. A., et al. (2018). Low-frequency rTMS in the superior parietal cortex affects the working memory in horizontal axis during the spatial task performance. Neurosci, 39(3): 527-532.

Sadeghi, N. G., et al. (2011). Neural correlates of subsecond time distortion in the middle temporal area of visual cortex. J Cogn Neurosci, 23:3829- 3840.

Saletu, B., et al. (2002). Classification and evaluation of the pharmacodynamics of psychotropic drugs by single-lead pharmaco-EEG, EEG mapping, and tomography (LORETA). Methods Find Exp Clin Pharmacol, 24(Suppl C): 97-120. 
Research, Society and Development, v. 10, n. 9, e33110918174, 2021

(CC BY 4.0) | ISSN 2525-3409 | DOI: http://dx.doi.org/10.33448/rsd-v10i9.18174

Salles, J. I., et al. (2006). Neuromodulatory effects of bromazepam when individuals were exposed to a motor learning task: quantitative electroencephalography (qEEG). Arq. Neuropsiquiatr, 64(1): 112-117.

Sampaio, I., et al. (2007). Influence of bromazepam on cortical interhemispheric coherence. Arq. Neuro-Psiquiatr,

Sampaio, I., et al. (2008). The influence of bromazepam on cortical power distribution. An Acad Bras Cienc, 80(2): 335 -340.

Schependom, J. V., et al. (2019). Altered transient brain dynamics in multiple sclerosis: Treatment or pathology? Hum Brain Mapp. 40(16): 4789-4800.

Schreckenberger, M., et al. (2004). The thalamus as the generator and modulator of EEG alpha rhythm: a combined PET/EEG study with lorazepam challenge is humans. Neuroimage, 22(2): 637-44.

Sigel, E., \& Ernst, M. (2018). The Benzodiazepine Binding Sites of GABAA Receptors. Trends Pharmacol Sci. 39 (7): 659-671.

Stewart, S. A. (2005). The effects of benzodiazepines on cognition. J Clin Psychiatry, 66(suppl 2): 9-13.

Summerfield, C., \& Mahgels, J. A. (2005). Coherent theta-band EEG activity predicts item-context binding during encoding. Neuroimage, 24(3): 692-703.

Votaw, V. R., et al. (2019). The epidemiology of benzodiazepine misuse: A systematic review. Drug Alcohol Depend. 1; 200: 95-114.

Womelsdorf, T., et al. (2006). Gamma-band synchronization in visual cortex predicts speed of change detection. Nature, 439(7076): 733-736. 